TAPROBANICA, ISSN 1800-427X. October, 2012. Vol. 04, No. 02: pp. 65-68.

(C) Taprobanica Private Limited, 146, Kendalanda, Homagama, Sri Lanka.

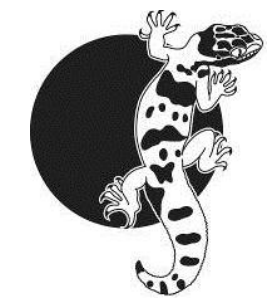

\title{
DESCRIPTION OF A NEW GENUS OF INDIAN SHORT-TAILED WHIP-SCORPIONS (SCHIZOMIDA: HUBBARDIIDAE) WITH NOTES ON THE TAXONOMY OF THE INDIAN FAUNA
}

Mandar L. Kulkarni

'Aashirvad', L. I. C. Colony-2, Near Rajiv Gandhi School, Latur- 413512, Maharashtra, India

E-mail: mandarkulkarni88@live.com

\begin{abstract}
Indian hubbardiids which were recently described but had doubtful generic placements are revised. The new genus Gravelyzomus is described here for Schizomus chalakudicus Bastawade, 2002. A new combination is proposed for Schizomus chaibassicus Bastawade, 2002 which is newly transferred to the genus Burmezomus.
\end{abstract}

Key words: Gravelyzomus, Burmezomus chaibassicus, Arachnida, taxonomy, India.

\section{Introduction}

The Indian species of the arachnid order Schizomida are very poorly characterized and represented by only six species: Tritheryus sijuensis Gravely, 1925; Ovozomus lunatus (Gravely, 1911); "Schizomus" kharagpurensis Gravely, 1912; Schizomus chaibassicus Bastawade, 2002; Schizomus chalakudicus Bastawade, 2002; and Neozomus tikaderi Cokendolpher, Sissom \& Bastawade, 1988. The first effort to study Indian schizomids was by F. H. Gravely who collected schizomids from India and surrounding countries, while Bastawade (1985, 1992, 2002, 2004) worked on Gravely's collection and described a few new species. Recently, Harvey (2011) transferred Schizomus lunatus to Ovozomus due to unusual morphology of female genitalia. Bastawade (2004) studied some species deposited by Gravely in the Zoological Survey of India (ZSI), and redescribed six species using criteria developed by Reddell \& Cokendolpher (1995), of which only two species were reported from India. Although preparing thorough descriptions, Bastawade $(2002,2004)$ maintained these species within the genus Schizomus and placed the generic name in inverted commas to indicate the uncertainty of the placement of the species in combination with the genus as given in Reddell \& Cokendolpher (1995). The descriptions provided by Bastawade (2002) provided illustrations of the propeltidium, pedipalp, 
female flagellum, spermatheca and gonopod, and the descriptions are generally detailed allowing comparison with other described material of the order. Reddell \& Cokendolpher (1991) redescribed Schizomus crassicaudatus O. Pickard-Cambridge, the type species of the genus Schizomus, and hence provided strong evidence to recognize and circumscribe this genus (see Reddell \& Cokendolpher, 1991).

This particular clarification provides many opportunities to compare the available data and recognize its placement of many species under given genera. I have visited the museum of ZSI-Kolkata where the type specimens of the Indian schizomids were deposited. Unfortunately the specimens could not be located there. Therefore, I have been forced to rely on the original descriptions and illustrations provided by Bastawade (2002, 2004). This study was designed to attempt to review the Indian schizomid fauna and establish whether they could be assigned to existing genera, based on the criteria developed by Reddell \& Cokendolpher (1995).

Family Hubbardiidae Cook, 1899

Gravelyzomus new genus

Type species: Schizomus chalakudicus Bastawade, 2002.

Diagnosis: The new genus Gravelyzomus differs from other Indian genera of order Schizomida by a combination of the following characters. Anterior process of propeltidium with a single median seta and pair of basal setae i.e. arranged in 1+2 manner; eye spots absent; metapeltidium divided. Pedipalpal trochanter without median spur, patella smooth and without any spur on ventro-lateral surface. Abdominal tergites and sternites smooth; setation not known for certain, except for dorsal median pair of setae on tergites I-IV. Flagellum with three segments, only lateral and dorsal pair of setae present on last annulus. Spermathecae tubuliform, with many irregular tubes.

Etymology: This genus is named after F. H. Gravely for his contributions to Indian arachnology, and the generic name Zomus. The gender is masculine.

\section{Description:}

Cephalothorax: Acutely pointing propeltidum bending forward with pair of basal setae, a median seta and three pairs of dorsal median setae. Sternal setae unclear.

Abdomen: Both sternite and tergite without clear setation. Flagellum three segmented. Spermathecae tubiliform, with many irregular tubes on each side.

Chelicerae with basal segment wide, movable finger without any teeth except for a single rounded tooth at distal end, immovable finger with three sharp teeth. Pedipalp with roughly triangular trochanter, with 5-6 spinose setae on exterior ventral margin, femur rounded with inner knob.

Distribution: Chalkudi, near Cochin, Kerela, India

Remarks: The phylogenetic relationship of Indian schizomids is not clear yet, so far this genus shows similarity with some Old World genera like Ovozomus and Trithyreus by having a divided metapeltidium, arrangement of setae on anterior process but differs by the spination on the abdominal tergites which are smooth in Gravelyzomus, and the structure of the spermathecae are also different i.e. spermatheca in Gravelyzomus has numerous lobes and irregular shaped gonopod.

Gravelyzomus chalakudicus (Bastawade, 2002), new combination

Schizomus chalakudicus Bastawade, 2002: 90-91, figs 1-13.

Holotype: ZSI (uncatalogued); adult female (5.59 mm TL); Chalkudi, near Cochin, Kerela, India; F. H. Gravely; 14-30 September 1914 (not examined).

Distribution: Chalkudi, near Cochin, Kerela, India. This species is known only from the type and no live population found during our field visits to the type locality.

Remarks: The holotype is currently lost or has been borrowed by a previous worker and not returned to the museum. The illustration of the spermatheca by Bastawade (2002) shows numerous irregular lobes on each side and a gonopod that is irregular in shape. The current placement of this species in Schizomus cannot be maintained, as the structure of spermathecae 
and the pedipalp differ from that of Schizomus (Reddell \& Cokendolpher, 1991). The spermathecal morphology does not match any known genus of the order; hence I here include this species in the new genus Gravelyzomus.

\section{Genus Burmezomus Bastawade, 2004}

Diagnosis: The genus Burmezomus differs from other Indian schizomid genera by a combination of the following characters. Propeltidium bent beak-like anteriorly with either 3 (median seta and pair of basal setae) or 2 (a pair of basal setae), dorsal setation not clear; eye spots absent; metapeltidium is medially separated by a suture or entire. Pedipalp patella with three spinous setae on ventral margin. Female flagellum with 1-3 annuli. Spermathecae with an uneven number of band-like structures, gonopod short.

\section{Burmezomus chaibassicus (Bastawade, 2002), new combination}

Schizomus chaibassicus Bastawade, 2002: 92, figs 14-26.

Holotype: ZSI (uncatalogued); adult female $(6.10 \mathrm{~mm} \mathrm{TL})$; Pass between Chaibass and Chakradharpur, Chota Nagpur, Bihar, India; P. E. Gravely; 1 October 1919 (not examined).

Distribution: Pass between Chaibass and Chakradharpur, Chota Nagpur, Bihar, India. This species is known only from the type and no live population found during our field visits to the type locality.

Remarks: The holotype is currently lost or has been borrowed by a previous worker and not returned to the museum. The original description of this species (Bastawade, 2002) was based upon a single female. The major characteristics, however, do not match with the diagnostic characters of the genus Schizomus (see discussion above). In particular, the structure of the female spermathecae differs from Schizomus, i.e. in the form of elongated lobes and in a cluster of 8-10. The female spermathecae more closely resemble the genital structure of Burmezomus Bastawade, 2004. Hence, Schizomus chaibassicus is hereby transferred from Schizomus to Burmezomus.

"Schizomus” kharagpurensis Gravely, 1912 Schizomus (Trithyreus) kharagpurensis Gravely, 1912: 108, 109-110, fig. C.

Trithyreus kharagpurensis (Gravely): Giltay, 1935: 7

Distribution: Kharagpur, West Bengal, India.

Remarks: The type specimen could not be located in the ZSI collection and is either lost or loaned to a previous worker and never returned to the museum. So this particular species is retained under the genus "Schizomus".

Table 1: Diagnostic characters of some Indian Hubbardiidae based on original descriptions

\begin{tabular}{|l|c|c|c|c|c|}
\hline & $\begin{array}{c}\text { Gravelyzomus } \\
\text { chalakudicus }\end{array}$ & $\begin{array}{c}\text { Ovozomus } \\
\text { lunatus }\end{array}$ & $\begin{array}{c}\text { Neozomus } \\
\text { tikaderi }\end{array}$ & $\begin{array}{c}\text { Trithyreus } \\
\text { sijuensis }\end{array}$ & $\begin{array}{c}\text { Burmezomus } \\
\text { chaibassicus }\end{array}$ \\
\hline $\begin{array}{l}\text { Female flagellum, } \\
\text { number of segments }\end{array}$ & 3 & 3 & 3 & $2 ?$ & 1 to 3 \\
\hline Gonopod shape & Irregular & $\begin{array}{c}\text { Short and } \\
\text { unequal size }\end{array}$ & $\begin{array}{c}\text { Short and } \\
\text { rounded }\end{array}$ & $\begin{array}{c}\text { Elongated } \\
\text { lobes }\end{array}$ & Elongated and lobate \\
\hline $\begin{array}{l}\text { Number of } \\
\text { spermathecal lobes }\end{array}$ & $\begin{array}{c}\text { Numerous } \\
\text { lobes }\end{array}$ & Four pairs & $\begin{array}{c}\text { Three to five } \\
\text { on each side }\end{array}$ & Two pairs & Eight to Nine lobes \\
\hline $\begin{array}{l}\text { Anterior setae on } \\
\text { metapeltidium* }\end{array}$ & $1+2$ & $1+2$ & $2+1$ & $2+1$ & $1+2 / 0+2$ \\
\hline Metapeltidium & Divided & Divided & Entire & Divided & Entire \\
\hline $\begin{array}{l}\text { Pedipalpal } \\
\text { trochanter }\end{array}$ & Eyespots absent & $\begin{array}{c}\text { Eyespots } \\
\text { absent }\end{array}$ & Eyes present & $\begin{array}{c}\text { Eyespots } \\
\text { absent }\end{array}$ & $\begin{array}{c}\text { Inconspicuous } \\
\text { eyespots present }\end{array}$ \\
\hline Corneate eyes & $\begin{array}{c}\text { Male not } \\
\text { known }\end{array}$ & $\begin{array}{c}\text { Sexually } \\
\text { dimorphic }\end{array}$ & $\begin{array}{c}\text { Sexually } \\
\text { dimorphic }\end{array}$ & $\begin{array}{c}\text { Male not } \\
\text { known }\end{array}$ & Male not known \\
\hline $\begin{array}{l}\text { Pedipalp sexually } \\
\text { dimorphic }\end{array}$ & Without spur & With \\
\hline
\end{tabular}

* First digit denotes number of setae on anterior most part of metapeltidium followed by number of setae located behind that. 


\section{Acknowledgements}

I am thankful to Lorenzo Prendini and Adalbarto Santos for their comments on first draft. I am grateful to $\mathrm{K}$. Venkatraman (Director - ZSI) for providing access to ZSI, also Basudev Tripathi and Sankar Talukdar (ZSI) for all help at ZSI-Kolkata. I would also like to thank Nikhil Bhopale (BNHS, Mumbai) and Kruti Chhaya (CES, Banglore) for sharing literature.

\section{Literature cited}

Bastawade D. B., 1985. The first report of the order Schizomida (Arachnida) from Southern India. Journal of the Bombay Natural History Society, 82 (3): 689-691.

Bastawade D. B., 2002. Two new species of schizomids from India with range extension for Schizomus tikaderi (Arachnida: Schizomida). Journal of Bombay Natural History Society, 99 (1): 90-95.

Bastawade D. B., 2004. Revision of some species of family Schizomidae (Arachnida: Schizomida) on the basis of types deposited by F. H. Gravely (1911-1925) in the National Collection, ZSI, Kolkata. Journal of the Bombay Natural History Society, 101 (2): 211-220.

Bastawade D. B. and T. K. Pal, 1992. First record of the arachnid order Schizomida from Arunachal Pradesh, India. Journal of the Bombay Natural History Society, 89 (1): 137.

Cokendolpher J. C., D. W. Sissom and D. B. Bastawade, 1988. A new Schizomus of Indian state of Maharashtra, with additional comments on eyed schizomids (Arachnida: Schizomidae). Insecta Mundi, 2 (2): 90-96.

Giltay L. 1935. Notes arachnologiques africaines. VII. Description d'um Pèdipalpe nouvaeu du Congo belge (Trythyreus ghesquierei, n. sp.). Bulletin du Musèe Royal d'Histoire Naturelle de Belgiue, Bruxelles, 11 (32): 1-8

Harvey M. S., 2011. Notes on some Old World schizomids of genera Ovozomus and Schizomus (Schizomida: Hubbardiidae). Records of the Western Australian Museum, 26: 202-208.
Reddell J. and J. Cokendolpher, 1991. Redescription of Schizomus crassicaudatus (Pickard-Cambridge) and diagnoses of Hubbardia Cook, Stenochrus Chamberlin and Sotanostenochrus new genus, with description of a new species of Hubbardia from California (Arachnida: Schizomida: Hubbardiidae). Texas Memorial Museum, Pearce-Sellards Series, 47: 124.

Reddell J. and J. Cokendolpher, 1995. Catalogue, bibliography and generic revision of the order Schizomida (Arachnida). Texas Memorial Museum, Speleological Monographs, 4: 1-170. 